\title{
Towards a New Paradigm of Education; The End of Positional Hegemonies
}

\author{
Prof. Dr. Emin Dogan Aydın
}

Faculty of Communication, Istanbul

\section{Aydın University}

Teaching courses about New Media simultaneously in the various years of an undergraduate curriculum has interesting consequences. It happens every semester again and again, that you discover some new development in your field and begin to discuss it with those who are close to their graduation and the newcomers at the same time. Than you tell your older students about this phenomenon of injustice, warning them that the younger are more lucky because they get acquainted with new inventions at an earlier stage; that the content of your syllabus is getting quickly outdated and has to be revised during each semester; and since you will not be available in their future life they should be alert and continue research in their professional life.

Knowledge today grows at an unprecedented pace. Both the available technologies and the social practices transform so rapidly that we cannot easily adapt to them with our habitual resistance to change. We have already entered the century of creativity and -innovation, not only to be appreciated but also to be performed by the masses. Transcending our traditional categories and values is a prerequisite for stepping into this new era.

\section{A Substantial Change in Established Roles}

The future of education will definitely be in a liberal direction. Passive learning methods are already obsolete. You cannot teach a course following a standard textbook anymore. Actually, most books in our libraries except the classics reveal not to be worth consulting for any kind of research, neither on academic or practical issues. 
The most recent knowledge is only available online -at everybody's reach. Thus experience acquired by age looses its primacy where all disciplines are in accelerating flux; and the novices are the real beneficiaries with their advanced skills in mining and processing global information resources, and the rapidly developing formats of communication.

Competence in reaching recent information on any subject matter has become the most critical offer expected from any educational program.

Under these conditions, active learning will no longer be a separate compartment of our lives but turn into an integral dimension of our daily struggle for survival. This is true both for the professionals involved in the development of new social practices and those who consider themselves as users only, because new and more complex types of human - machine interaction invade our lives rapidly, and everyone has to be competent in them not only to consume but to utilize them to develop their business and/or productive activities.

The youngest are the most competent in technologies and conventions that develop in conjunction with the various forms of New Media. Referring to unpublished research data from a project at The Danish University of Education, Tweddle Levinsen (2007) recently wrote about the story of two children (age 9 and 10 years) who multitask and handle complex and relatively abstract information as they navigate between applications and multiple windows within these applications. They manage to design a layout for the narrative, discuss the wording and spell correctly. She refers to S0rensen (2005) who describes such kids as either 'competent' or 'power users':

"The kids represent a process, where the educational system's Traditional, hierarchical 'food chain' from teacher to inexperienced pupils and students, seems to disintegrate into horizontal networked relations. In the latter, roles are intertwined and informal learning processes become common (Trilling and Hood 2001). What is new here is that kids learn and use ICT, which is paramount for dealing with and participating in the emerging information society, and that their teachers do not." 
She has also developed a flowchart illustrating how the new generations will eventually join higher education;

"The conflicts arising are not just a matter of contrasting societal paradigms. The paradigms are embedded in the generation, the process bridges a generation gap that may continue for decades. Thus, organizations' readiness for change becomes highly important." (Tweddle Levinsen, 2007)

A disturbing consequence of this situation might be that our personal investments on educational background, specialization, and intellectual property will be degrading in terms of their exchange value. It is already a fact that diplomas from traditional institutions will have little validity for tasks that require contemporary competencies or for the management of decisions related to them.

We can say that capital and property, either in their material, monetary, or intellectual forms will loose their established importance as our primary assets. In a world of flux, personal competencies, the use value of human resources, will determine success.

\section{New Principles for Collaboration}

Contemporary developments may seem to point to a direction of competitive individualism but, paradoxically, sharing information, knowledge, and ideas even at the forefront of innovative developments has become the rule for individual success, too. Even tacit knowledge, definitive for specializing in a profession and supposedly our most private asset, has to turn explicit and be shared in the context of a community to be updated and grow properly as fits the age of democratic networking.

As constructivist ideas in educational theory well represent, students do not passively receive knowledge, but rather actively assimilate it. In the coming era, it will be much more crucial than it was in the past that each individual has the capacity and urge to

- constantly structure the acquired information towards the status

of knowledge, and 
- further existing knowledge in collaboration.

These are well-developed, almost instinctive skills for academically oriented people, but most students in an institutional context refrain from manipulating and propagating what they are presented in a traditionally formatted, aesthetic zed and authoritative style. The very presence of the instructor in a classroom, in this respect, usually has a discouraging rather than stimulating effect on participation.

In real university settings 'Positional' relationships dominate and effect the active involvement of the students in a negative way. They should rather be allowed to feel like their own boss and take command with their individual initiatives in a democratic setting where everyone has the same responsibility for the results of the cooperative learning process.

It is an imperative under these conditions that the role of the teacher has to be basically revised.

Our use here of the term 'positional' resembles the terminology of the late Mary Douglas, as when she developed a graph on the axes of Structural Grid / Group' (Rules and Roles) explaining two types of culture, namely positional and individualistic: "When two dimensions arrive at their maximum, this means strong group, strong regulation. All roles will be predetermined, all behavior is subject to 'positional' rules indicated by heredity, or gender, or age, and combinations of all three." (Douglas, 2005) We can say that we can easily extend this explanation to teacher / student relationships. Traditional patterns of education are defined by 'Positional' relationships whereas the coming age of creativity already demands individualistic capacities from all its members.

Douglas' further suggestions, by analogy, can also apply to our case:

"On apathy CT can be illuminating. Development Economists often find their best efforts thwarted by the apathy of the people whose lives they want to improve. Apathy is the response to lack of opportunity. Cultural theory has an explanation and a remedy. It should be a prime concern of development 
officers to remove barriers to personal advancement, and, if they want to see their work bear fruit, to encourage a culture of competitive individualism."

In this respect maybe, we should also remember Bernstein (1971) for his definitions of "elaborated speech codes" of the contemporary middle classes strenuously seeking upward mobility, and " restricted speech codes" of working classes, stuck where they are. The "elaborated code" was more advantageous in the context his work was based. But when reviewing his ideas for the Guardian after his death, John Charap drew our attention to a new reading of his position:

"It was a theory of speech forms responding to two types of social control, one through positioning and one through individualizing. (...) Paradoxically, the critics in socio-linguistics suspected him of bias against the underprivileged, a bizarre perversion of his attitude. Bernstein admired the " restricted code", as he called it, for its power, directness, wit, and vivid, dramatic effects."

New directions in Situational Analysis in Social Theory try to formulate a new outlook that Is not discriminating against various personal styles in social interactions as suitable but acknowledges all choices as situation ally meaningful.

"Further, I would argue that we need at least a century's worth of attempting to take differences seriously empirically through a variety of innovative methodologies. Individual and collective difference(s) in our situatedness and practices need to be capable of being taken into account in social life and in social policies of all kinds from education to welfare reform to health coverage and care giving to social security in old age. If we lack both an adequate vocabulary and research methods to specify at least genres of difference, we will continue to be paralyzed in terms of constructing ways of sharing the planet that work effectively toward greater social justice and more democratic participation. Such visionary Deweyian aspects of pragmatism are alive and well after the postmodern turn for good reason-because they are sorely needed. But they also need to be recast in ways that allow the explicit acknowledgment and incorporation of the complexities of situatedness, variation, and difference(s) rather 
than promoting their erasure through various assimilations or hopes for transcendence through shared education or shared beliefs." (Clarke, 2005)

Our basic proposition here is that positional advantages are all together losing their relevance for controlling interactions by any means, and we should design our scenarios for social settings accordingly. As a principle, we should prefer diversity rather than consistency, and praise content rather than form.

And this requires a reflective praxis that is crucial for understanding and overcoming positional hegemonies in the moderated setting.

"As with Enlightenment skepticism, positional reflexivity goes into competition with commonsense worlds. (...) At least since Plato's allegory of the cave, disciplined skepticism has promised an epistemic and methodological advantage over our naive knowledge of worldly appearances, and in many of its expressions, positional reflexivity reissues this venerable ambition of seeing through the naive -and even false- realisms of ordinary experience. Each seeks a critical understanding of ordinary worlds by reference to large but unnoticed arrangements and conditions - although now to reveal unseen power, discourse, and hegemony rather than Enlightenment themes of order, reason, or consensus." (Macbeth, 2001)

It is no more individual victories but the common goal that motivates competition in the new collaborative environments. Axel Honneth, a very influential contemporary German philosopher tries to formulate a new moral standard as a way out of the impasse of harsh individualism toward collaboration in competition:

"In modern societies, therefore, social relations of symmetrical esteem between individualized (and autonomous) subjects represent a pre-requisite for solidarity. In this sense, to esteem one another symmetrically means to view one another in light of values that allow the abilities and traits of the other to appear significant for shared praxis. Relationships of this sort can be said to be cases of 'solidarity', because they inspire not just passive tolerance but felt concern for what is individual and particular about the other person. For only to the degree to which I actively care about the development of the other's characteristics (which seem foreign to me) can 
our shared goals be realized." (Honneth, 1996)

On the other hand, all these do not mean that the teacher or moderator in collaborative settings -whether in the classroom or online- should push the silent members to contribute. Discussing the role of dialog in education with reference to cultural politics, Burbules (2006) says that, "Dialogue is neither a good nor a bad thing, in itself, and the decision about whether to teach with dialogue, when, and with whom -or, on the other side, the decision to participate in it, or not (whether, when, and with whom)- needs to be made within a broader political analysis of identity, interest, and purpose. (...) In progressive classrooms, these values are embedded in a larger vision of social liberation and teaching as an expression of political commitment; here, it can be particularly difficult -and threatening-to explore the possibility that one's own teaching and good intentions can be part of the problem."

Referring to Alison Jones $(1999,2004)$ he discusses the potential discontents of dialogues:

"The desire for dialogue can carry its own kinds of coercive influence. When people from different backgrounds try to discuss their experiences and differences-as often happens in multicultural classrooms - they are put in asymmetrical positions of risk and self-disclosure. Who are these conversations for, and who do they benefit? When multicultural educators talk about the virtues of cross-cultural understanding, this is tilted almost always in the direction of the supposed benefits of dominant groups coming to better understand members of no dominant groups." Burbules (2006)

Our opinion is that it is not dialogs -with mostly reactionary and uncalculated comments- but prepared presentations that are much more effective in learning processes. As the academics well know, teaching is the best way of learning. The responsibility of making presentation in a community context has actually the same effect because one feels obliged to be prepared: make prior research; restructure the results to understand to be able to clearly formulate them. This way all participants turn teachers of the classroom whether in real or cyberspace.

The same can be said about the notion of "social capital" (Bourdieu, 1977). We prefer to refer here to social capital as a collective achievement rather than an individual asset. 
Originally, Bourdieu's conception of social capital stresses that it operates as a tool for cultural hegemony in explaining unequal educational achievement. But O'Brien and Fathaigh (2004) argued -referring to Coleman-that,

"Social capital's potency is realized in its capacity (just like physical and human capital) to facilitate productive activity. This is achieved through the formation of social relationships built up over time which enables individuals to achieve their interests over-and-above those that can only be attained independently. Four important forms of social capital are identified: a) obligations and expectations (e.g. doing favors for and receiving favors from other people), b) informational potential (e.g. sharing useful information that may inform some future action), c) norms and effective sanctions (e.g. the establishment of community values and shared standards of behavior) and d) authority relations (e.g. skilful leadership that informs others' actions). It is noted that social capital through these means can benefit others who do not directly participate."

As we witness the transformation of mass media into new formats of many-to-many communication platforms, we may also expect now a similarly drastic change in our "modern" institutions of education. As everyone becomes a citizen journalist, everyone competent in new media will also turn into a citizen scholar.

\section{Democratizing Knowledge and Creativity}

Richard Hall (2006) similarly tries to formulate strategies for enfranchising elearners.

"The need to explore the learner's view of change pivots around the interventionist roles of academics and the epistemological spaces that they create. (...) theme of enfranchisement via increased freedom-of-action requires engagement with the social context in which it takes place, and therefore builds a sense of belonging. It stems from empowerment rather than coercion. (...) For learners, The mode of incorporation into these social spaces enables them to make sense of the world 
and therefore become independent. The ability to forge innovative and secure approaches to the critique of both knowledge and the frameworks that help us to interpret it, is crucial for the development of learning. (...) However, both learners and tutors have to want enfranchisement."

E-Literacy constitutes only the initial phase of an era that will be characterized by the consequences of peer-generated content and peer-to-peer transaction in online learning communities. These lifelong learning contexts require and induce creativity more than ever. This also implies a new lifestyle where:

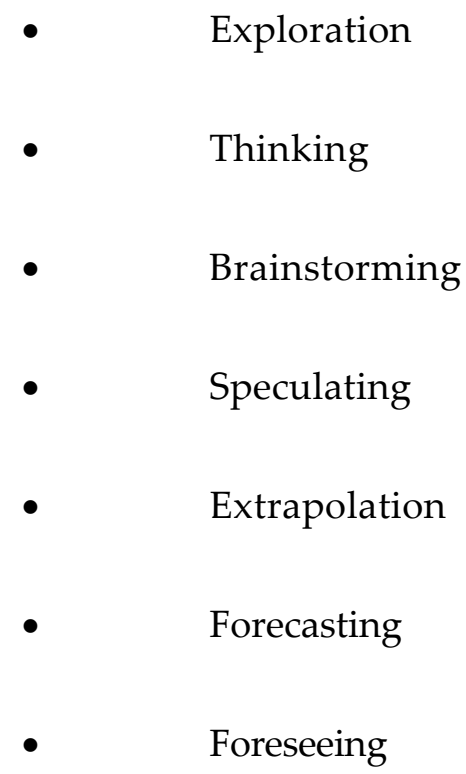

...will become attitudes expected to be acquired by everyone and especially supported by institutional education.

The collaborative contexts discussed above may encourage creativity but it will mostly be the success stories of innovative people around us and the failure of conservative/moderate lives that will be promoting the courage to creativity as the only reasonable way to survive.

Consequently, the future of education, in general, will develop on two converging trends:

1. New models of online programs for higher education 
2. Informal global online communities of practice on specific topics

These developments will focus on two historical tasks:

1. The transcoding of traditional frameworks of training and education into cyberspace with the provision of most enriched online resources and advanced transaction tools;

2. Organizing of desperate individual efforts toward a common global aim.

Delanty (2001) provided us with a contemporary critique of the university, connecting this to the end of modernity at large:

"I am suggesting that something like a cognitive shift is occurring today in the decline of Enlightenment's republic of science'. With the rise of critical publics the demand for democratization has penetrated the heart of cognitive rationality in calls for the public accountability of science. This cognitive shift can be seen as a communicative one, but one that is challenged by a neoliberal understanding of the university. Once standing on the secure ground of the Enlightenment and the national state, the university now finds itself occupying the uncertain terrain of shifting forms of knowledge at precisely the time that the nation state is entering a period of decline. The Age of Big Science, has suffered the fate of Big Government: its legit Imation has gone but the reality is still with us. No longer protected from democracy, the logic of communicative rationality has entered the academy calling into question the old cognitive models of neutrality, universality and objectivity."

All these insights reflect the end of mass education and mass media both symbols and generators of the modern conscience and the 20th Century. Positional hegemonies, at every scale from international to interpersonal, are at stake following the developments in ICT. Meditating on their absence can be helpful in understanding the social, political and economic changes expected to characterize the 21st Century. 


\section{References}

Bernstein, B. (1971) Class, Codes and Control, Vol. 1. London: Routledge \& Kegan Paul.

Bourdieu, P. (1977) Outline of a Theory of Practice. Translated by Richard Nice: Cambridge, Cambridge University Press.

Burbules, Nicholas C. (2006) "Rethinking Dialogue in Networked Spaces" Critical Methodologies, 2006; 6; 107. Available online at csc.sagepub.com/cgi/content/refs/6/1/107

Charap, John M (2000) "Basil Bernstein: Socio-linguist whose pioneering work on class and language changed the course of education" The Guardian, September 27, 2000. Available online at www2.ocn.ne.jp/ yamanobo/systemic_bibliography/to_and_with_h alliday/basil_bernstein_died.html

Clarke, Adele E. (2005) Situational Analysis: Grounded Theory After The Postmodern Turn. Sage Publ. Prologue available online at http://situationalanalysis.com

Delanty, Gerard (2001) Challenging Knowledge: The University in the Knowledge Society. Buckingham: Society for Research Into Higher Education.

Douglas, Mary (2005) "Grid and Group, New Developments" Paper prepared following the Workshop On Complexity and Cultural Theory in Honour of Michael Thompson held at the LSE on 27 June 2005. Online at www.psych.lse.ac.uk/complexity/Workshops/MaryDouglas.pdf

Hall, Richard (2006) "Delivering What Students say they Want Online: Towards Academic Participation in the Enfranchisement of e-Learners?" The Electronic Journal of e-Learning, Volume 4, Issue 1, March 2006. http://www.ejel.org/volume-4/v4-il/v4-il-art-4.htm 
Honneth, Axel (1996) The Struggle for Recognition: The Moral Grammar of Social Conflicts. MIT Press. (Chapter 5 available online at http://www.ethicalpolitics.org/blackwood/honneth.htm)

Macbeth, Douglas (2001) "On Reflexivity in Qualitative Research: Two Readings, and a Third" Qualitative Inquiry, 7; 35 The online version of this article can be found at: http://qix.sagepub.eom/cgi/content/abstract/7/1/35

Robberecht R (2007) "Interactive Nonlinear Learning Environments" The Electronic Journal of e-Learning Volume 5, Issue 1, pp 59 - 68, available online at www.ejel.org

Robins, Kevin, and Frank Webster, ed. (2003) The Virtual University? Knowledge, Markets, and Management. Oxford University Press.

S0rensen, B. H. (2005): "ICT and Schools in the Information Society". In: M. Chaib and A. Svensson (eds.): ICT and Schools in the Information Society.

Trilling, B and Hood, P. (2001): "Learning, Technology, and Education Reform in the Knowledge Age or "We're Wired, Webbed, and Windowed, Now What?"'. In: C. Paechter, R. Edwards, R. 
Harrison and P. Twining (Eds.), Learning, space and identity. London: Poul Clapman Publishing Ltd.

Tweddell Levinsen K (2007) "Watch out - the Power Users are Coming" The Electronic Journal of e-Learning, Volume 5 , Issue 1, pp 79 - 86, available online at www.ejel.org

Tweddell Levinsen, Kevin (2007) "Watch out - the Power Users are Coming" The Electronic Journal of e-Learning Volume 5, Issue 1, pp 79 - 86, available online at www.ejel.org/Volume-5/v5-

i1/Tweddell_Levinson.pdf 